\title{
Quantifying nitrous oxide emissions in the U.S. Midwest - A top-down study
}

M. Eckl ${ }^{1}$, A. Roiger ${ }^{1}$, J. Kostinek ${ }^{1}$, A. Fiehn ${ }^{1}$, H. Huntrieser ${ }^{1}$, C. Knote ${ }^{2}$, Z. Barkley ${ }^{3}$, S. Ogle ${ }^{4}$, B. Baier ${ }^{5,6}$,

C. Sweeney ${ }^{5}$, K. Davis ${ }^{3}$

${ }^{1}$ Deutsches Zentrum für Luft- und Raumfahrt (DLR), Institut für Physik der Atmosphäre, Oberpfaffenhofen, Germany

${ }^{2}$ Ludwig-Maximilians-University (LMU), Meteorological Institute, Munich, Germany

${ }^{3}$ Department of Meteorology and Atmospheric Science, Pennsylvania State University,

University Park, PA, USA

${ }^{4}$ Natural Resource Ecology Laboratory, Colorado State University,

Fort Collins, CO, USA

${ }^{5}$ Cooperative Institute for Research in Environmental Sciences,

University of Colorado-Boulder, Boulder, CO, USA

${ }^{6}$ NOAA Global Monitoring Laboratory, Boulder, CO, USA

${ }^{7}$ Earth and Environmental Systems Institute,

Pennsylvania State University, University Park,

PA, USA

Eckl, M., A. Roiger, J. Kostinek, A. Fiehn, H. Huntrieser, C. Knote, Z. Barkley, S. Ogle, B. Baier, C. Sweeney, K. Davis; Quantifying nitrous oxide emissions in the U.S. Midwest - A topdown study using high resolution airborne in situ observations; submitted to Geophysical Research Letters on October 14, 2020. 
$\mathrm{N}_{2} \mathrm{O}$ plays a crucial role in the atmosphere.

Dominant ozone-depleting substance

(Ravishankara et al., 2009)
Third most important long-lived anthropogenic greenhouse gas (Myhre et al./IPCC AR5, 2013)

\section{Atmospheric abundance:}

- Rising since industrialization ( 20\%)

(McFarling Meure 2004 \& 2006)

- Globally in January 2020: 330 ppb (Combined Nitrous Oxide data from the NOAA/ESRL Global Monitoring Division)

\section{Emissions:}

- Recent growth in emissions increased at a higher rate than expected

(Thompson et al., 2019; Tian et al., 2020)

- Interest grows in expanding efforts to reduce emissions

(Kanter et al., 2020) 
The agriculture in the Midwest is a hotspot of $\mathrm{N}_{2} \mathrm{O}$ emissions.

- Agriculture/Application of nitrogen fertilizer is the main anthropogenic source.

- U.S. Cornbelt within the Midwest is a wide area, dominated by agricultural activity

$\rightarrow$ The Midwest is a regional hotspot of agricultural $\mathrm{N}_{2} \mathrm{O}$ emissions

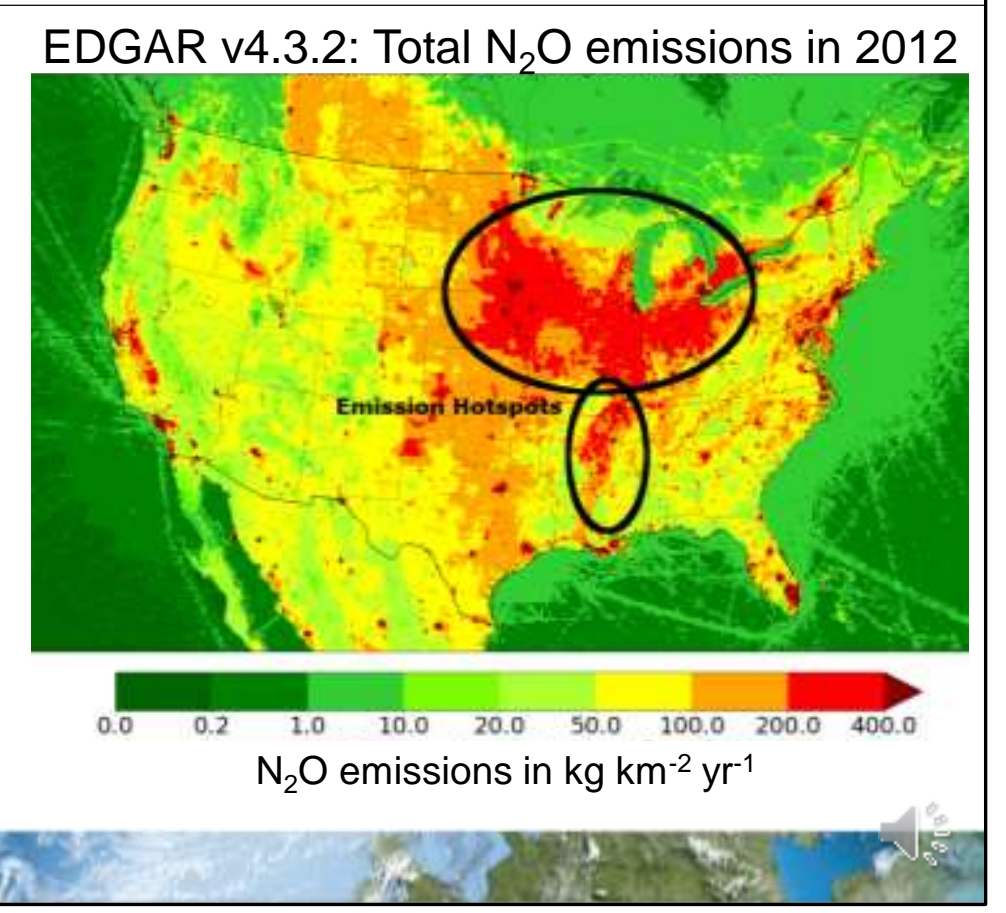




\section{Midwest $\mathrm{N}_{2} \mathrm{O}$ emissions are highly uncertain.}

\section{Current knowledge:}

- Limited amount of top-down studies

- High regional uncertainties in common inventories like EDGAR

e.g.: Fu et al., 2017: agricultural EDGAR v4.2 emissions in the Cornbelt must be multiplied by a factor up to 19.0 - 28.1 (tall tower measurements + WRF-Chem)
How high are $\mathrm{N}_{2} \mathrm{O}$ emissions in the Midwest?

How well are these emissions represented in state-of-the-art bottomup inventories? 
Airborne in situ $\mathrm{N}_{2} \mathrm{O}$ measurements from ACT-America campaigns.

\section{ACT-America fall 2017 \& summer 2019}

Measurements onboard NASA's C-130:

- Quantum Cascade Laser Spectrometer (QCLS; DLR) (Kostinek et al., 2019)

$\rightarrow$ continuous in-situ measurements

- Flask measurements (PFP; NOAA; Colm Sweeney \& Bianca Baier) (Sweeney et al., 2015, 2018; Baier et al., 2020)

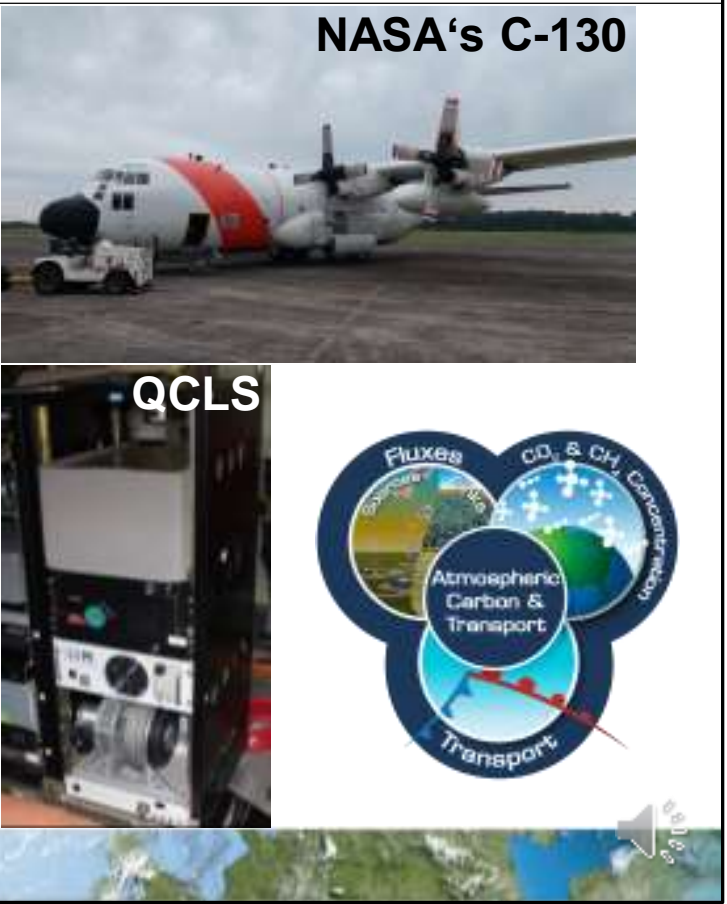


Selecting ACT-America transects over the Midwest.

\section{ACT-America fall 2017 \& summer 2019}

Transects within the PBL over the Midwest required

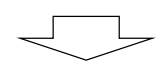

Selected:

- Four flights of October 2017

- Six flights of June/July 2019

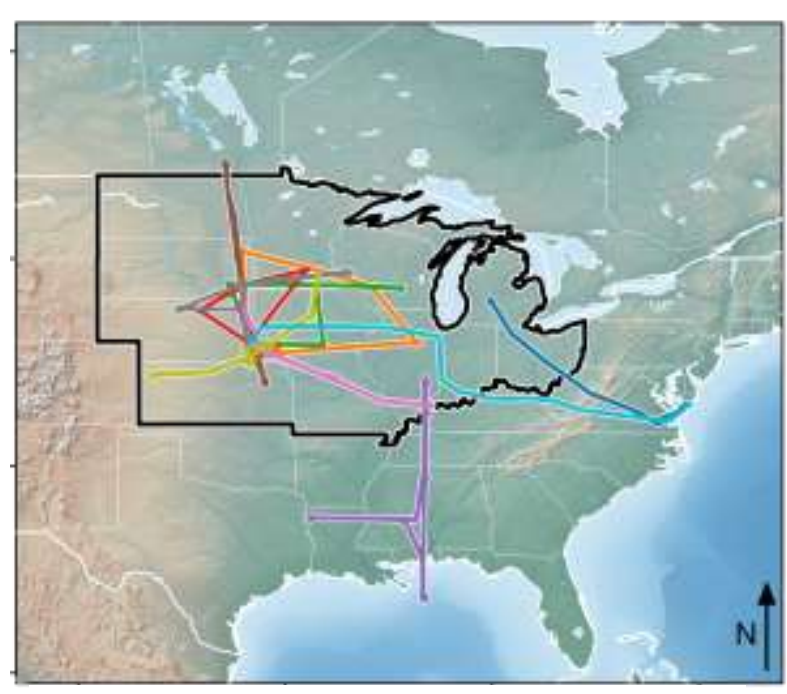


Quantifying Midwest $\mathrm{N}_{2} \mathrm{O}$ emissions with a top-down approach.

(Approach comparable to Barkley et al., 2017)

Airborne in situ $\mathrm{N}_{2} \mathrm{O}$

measurements over the

U.S. Midwest

$+$

Forward simulation with

WRF-Chem

$+$

emission inventory 
Simulating $\mathrm{N}_{2} \mathrm{O}$ plumes with WRF-Chem forward simulations.

WRF-Chem version 4.0.2 forward simulations

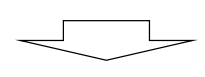

Emit $\mathrm{N}_{\mathbf{2}} \mathrm{O}$ from bottom-up inventory (Atmospheric lifetime of $\mathrm{N}_{2} \mathrm{O}: 118$ years (Prather and $\mathrm{Hsu}, 2010) \rightarrow$ passive tracer)

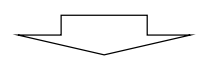

Simulated plume along PBL transect

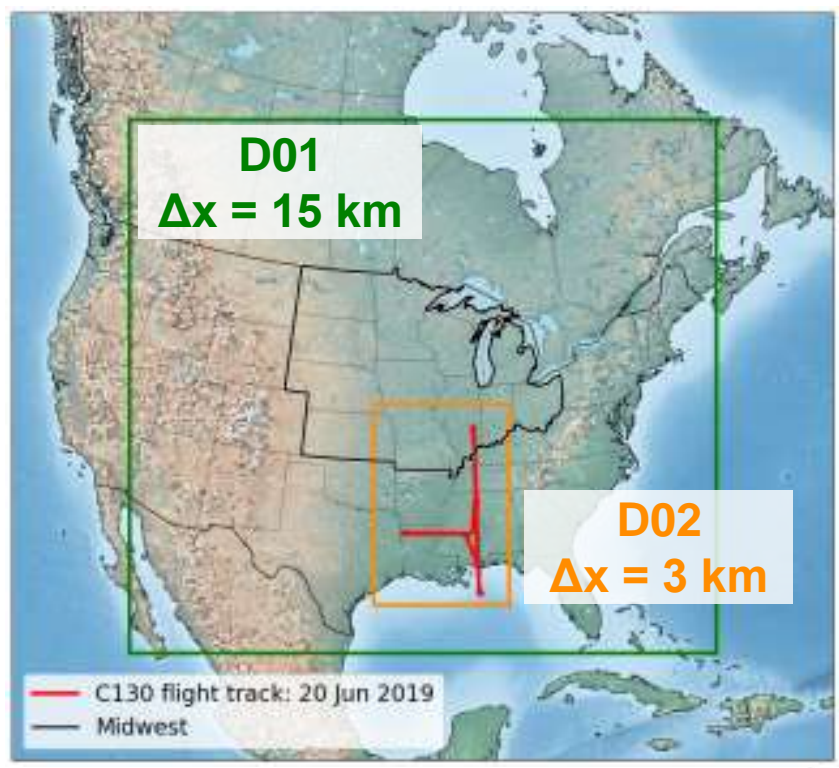




\section{Obtaining prior emission estimates for simulations from EDGAR.}

Employed bottom-up inventory: Emissions Database for Global Atmospheric Research

- Anthropogenic emissions: EDGAR v4.3.2 (2010) and EDGAR v5.0 (2015)

- Natural: EDGAR v2 (1990)

Merging emission sectors to:

1. Agricultural (AGR)

2. Non-agricultural anthropogenic (nonAGR)

3. Natural (N)

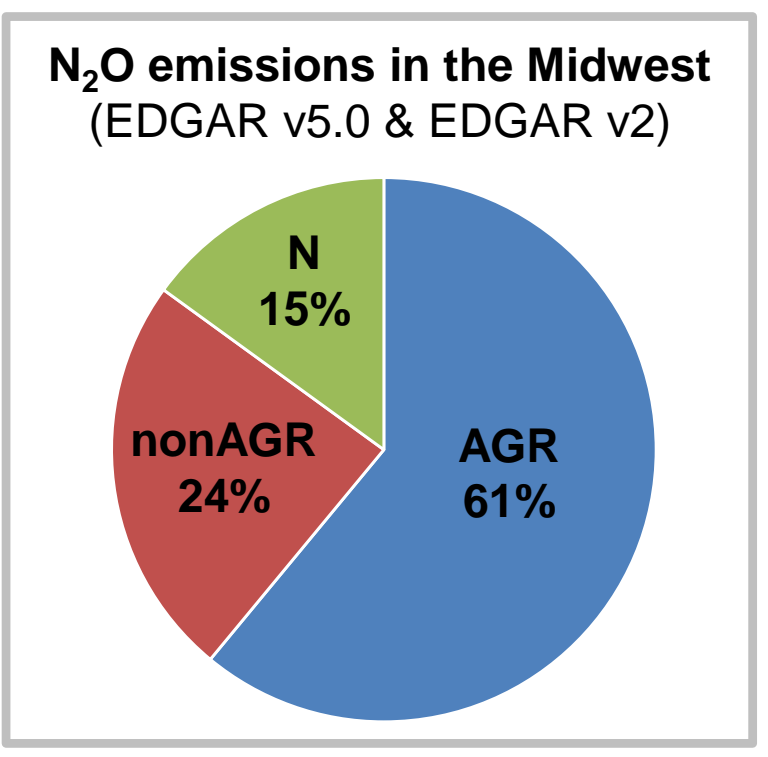


Quantifying Midwest $\mathrm{N}_{2} \mathrm{O}$ emissions with a top-down approach.

(Approach comparable to Barkley et al., 2017)

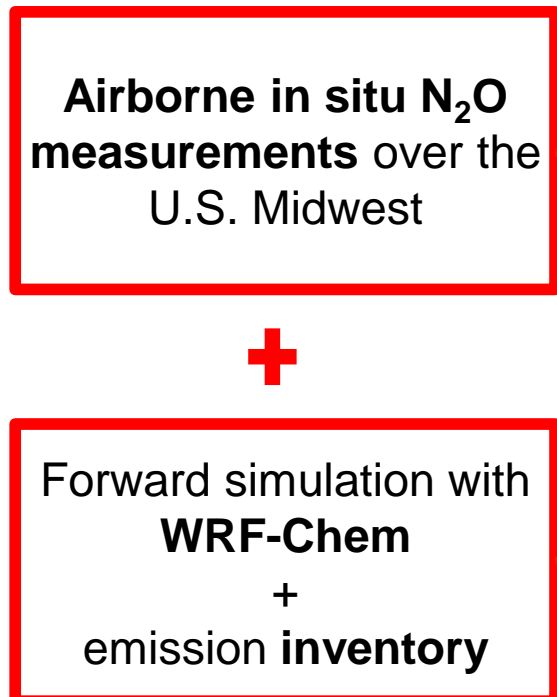

Compare simulated

enhancements in the atmosphere with measurements
Adjust inventory so that differences between simulation and measurements are minimal 


\section{Large discrepancy between observed and simulated plume}

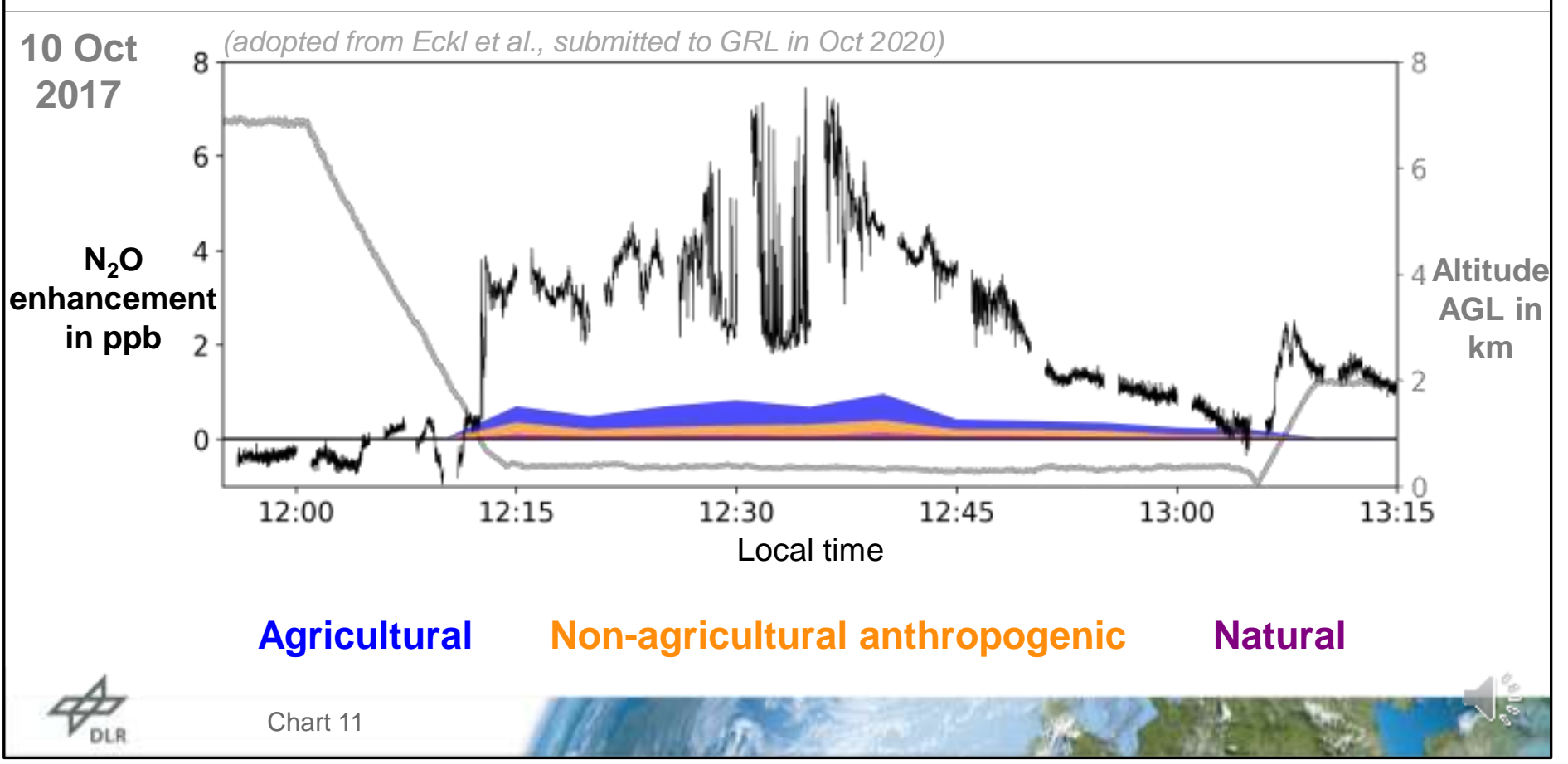


Adjusting the inventory by scaling agricultural emissions.

Dominant source:

Agricultural emissions
Complexity of $\mathrm{N}_{2} \mathrm{O}$ soil emissions

$\rightarrow$ agricultural emissions exhibit much higher uncertainties than others

(Butterbach-Bahl et al., 2013)

\section{Assumption:}

Discrepancy between simulation and observations is caused by agricultural emissions

Adjust inventory by scaling agricultural emissions 
Scaling agricultural emissions minimizes the discrepancy.

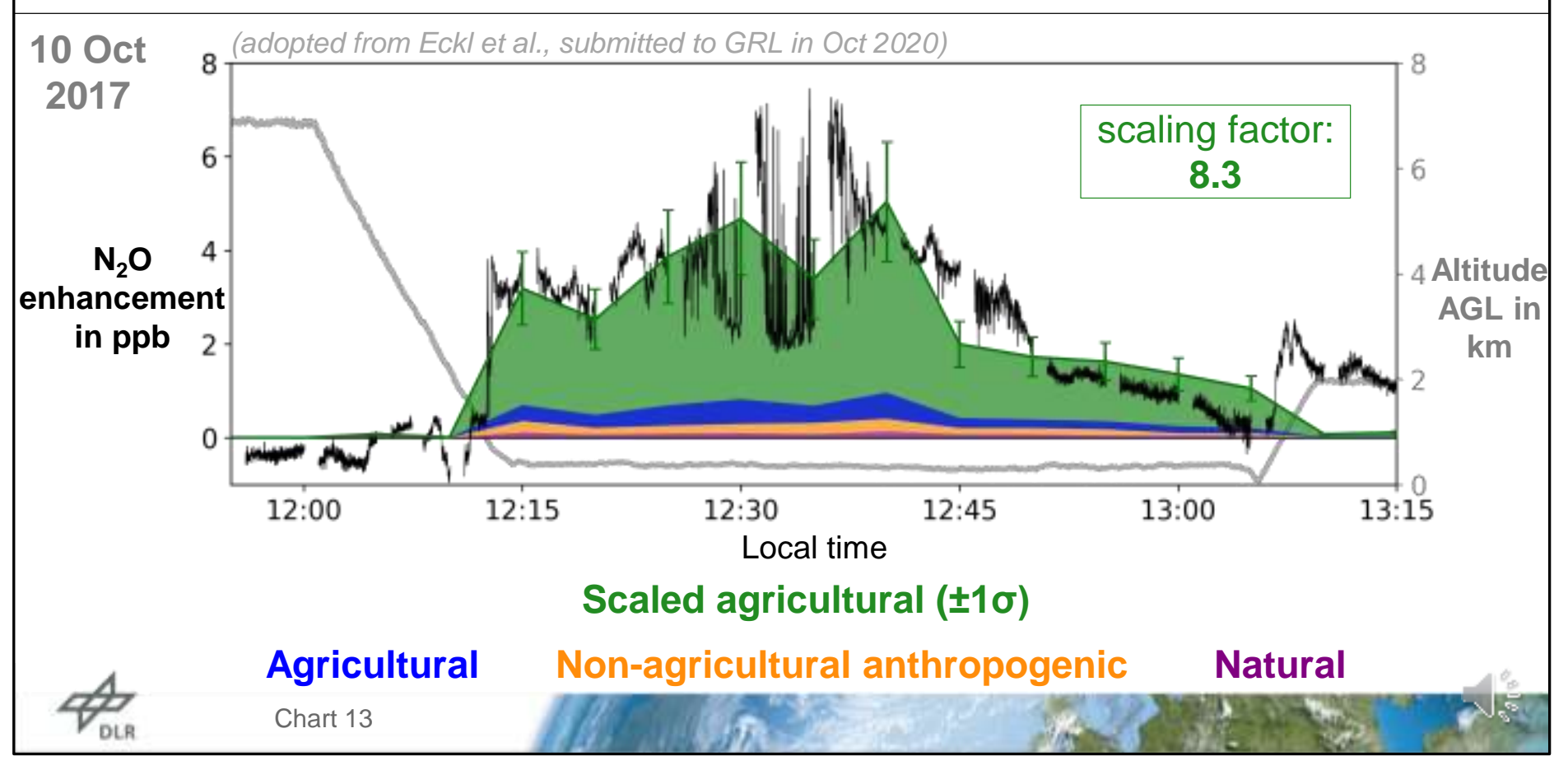




\section{EDGAR strongly underestimates agricultural Midwest emissions.}

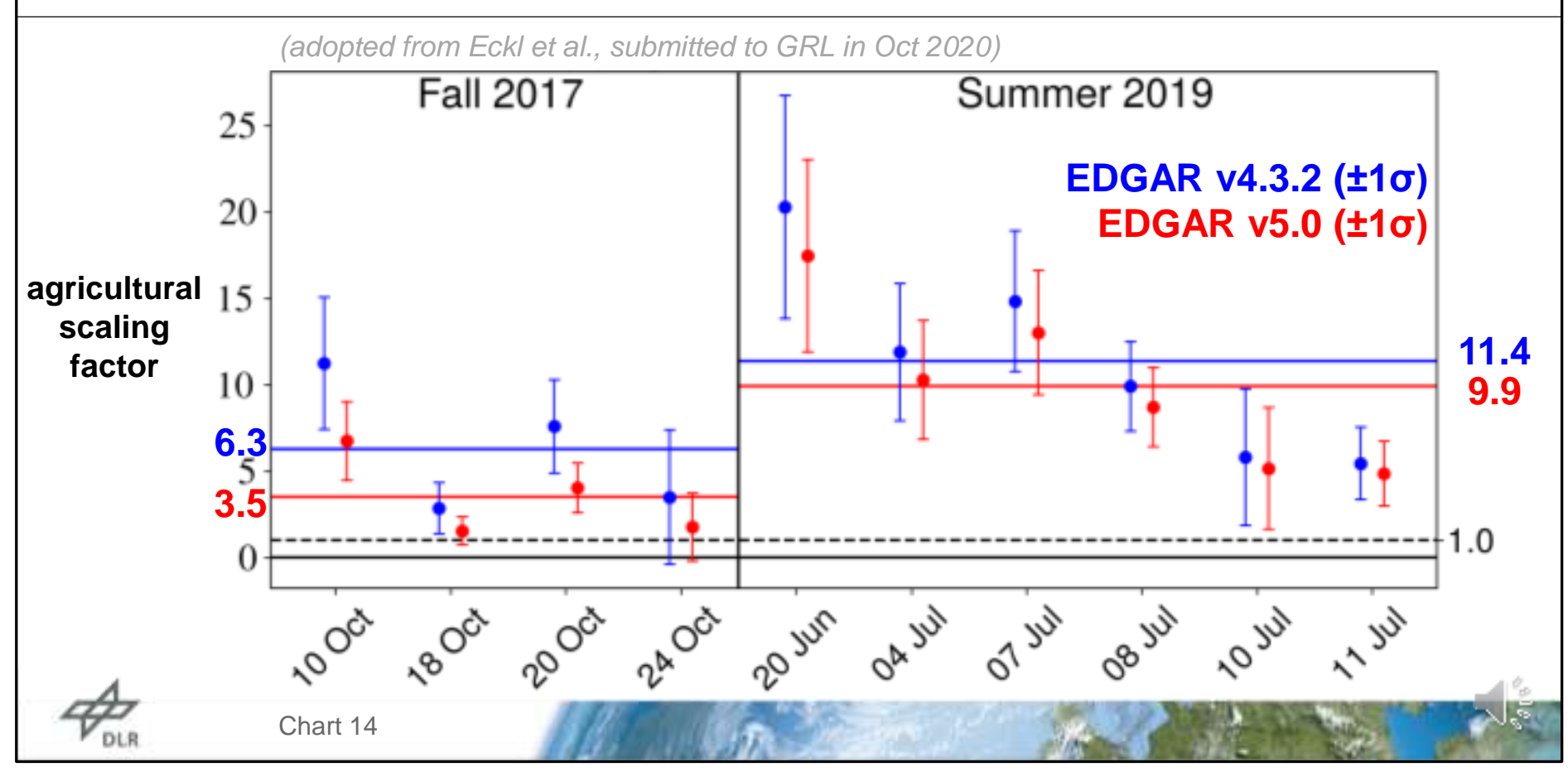


Midwest $\mathrm{N}_{2} \mathrm{O}$ emissions are strongly underestimated by EDGAR.

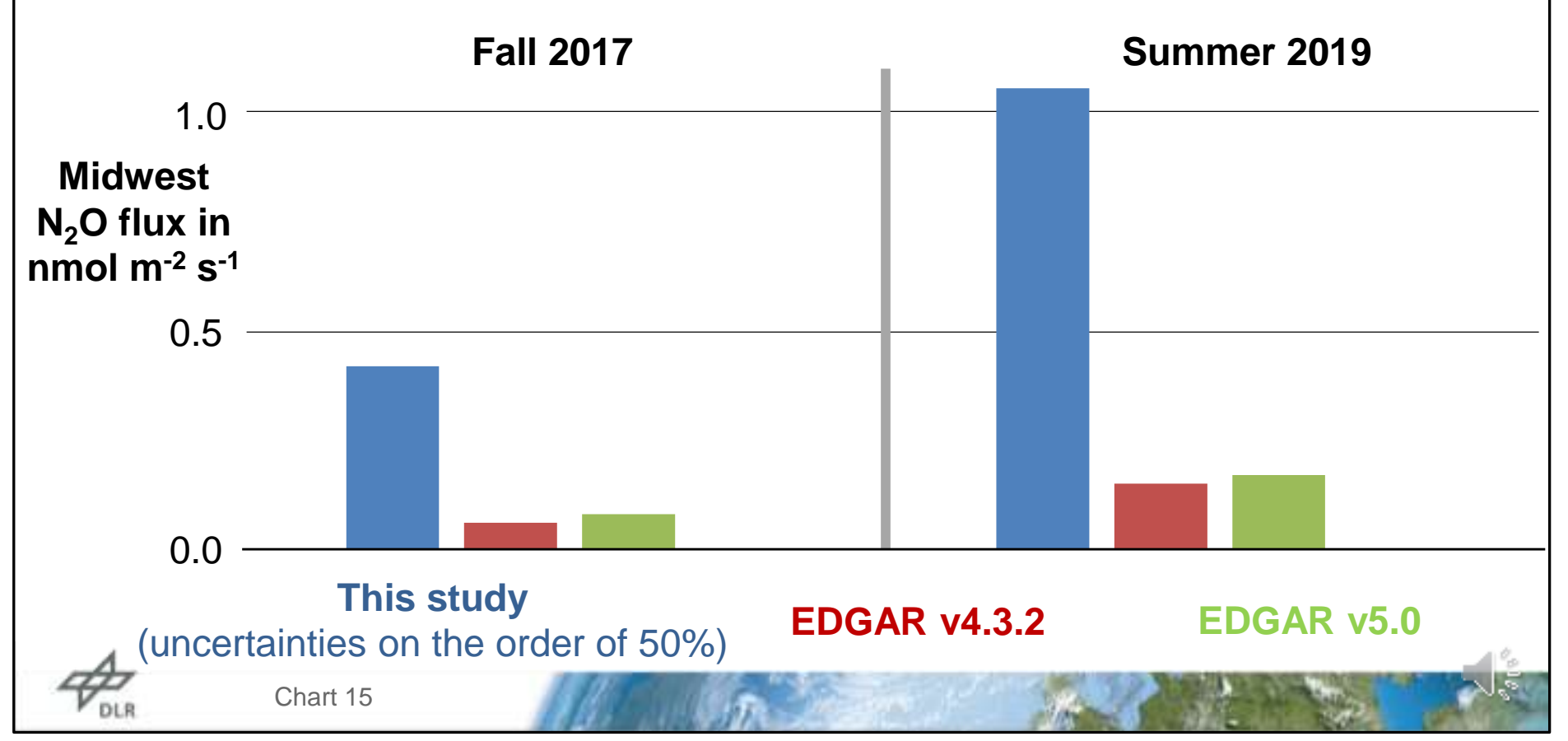




\section{How much contributed the severe flooding event in 2019?}

Spring/early summer 2019

Wettest period in 125 years in the U.S, with

severe flooding in the Midwest

(NOAA, 2020)

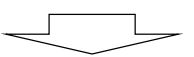

Contribution to our June/July 2019 result?!

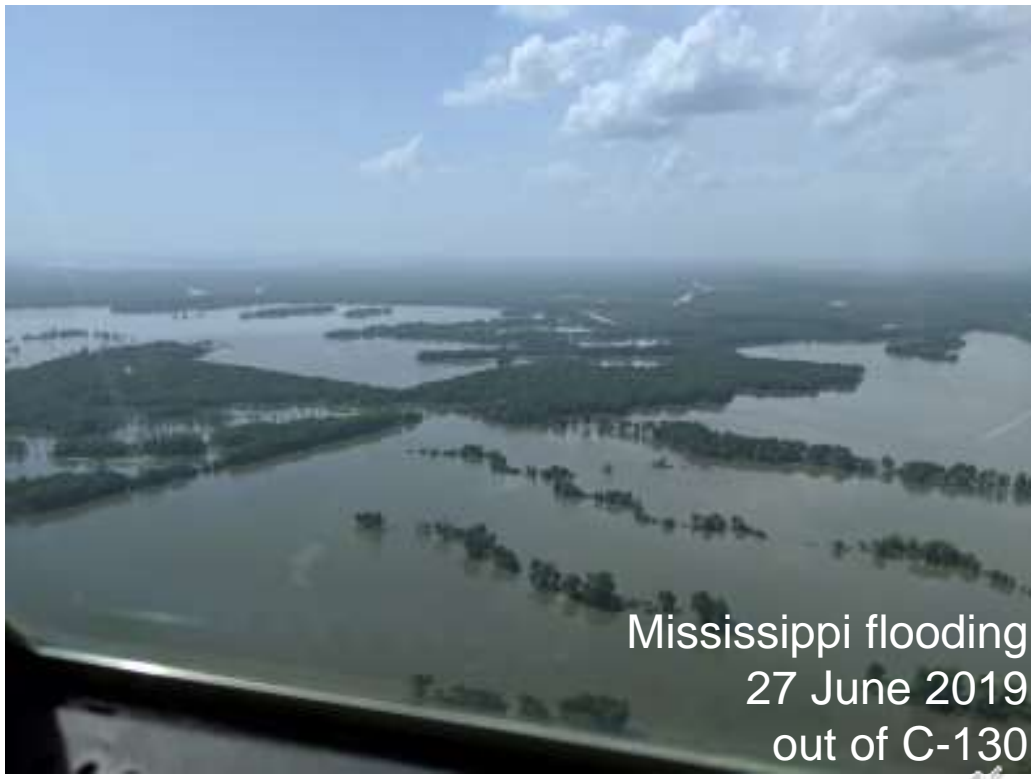


DayCent provides more sophisticated bottom-up estimates than EDGAR.

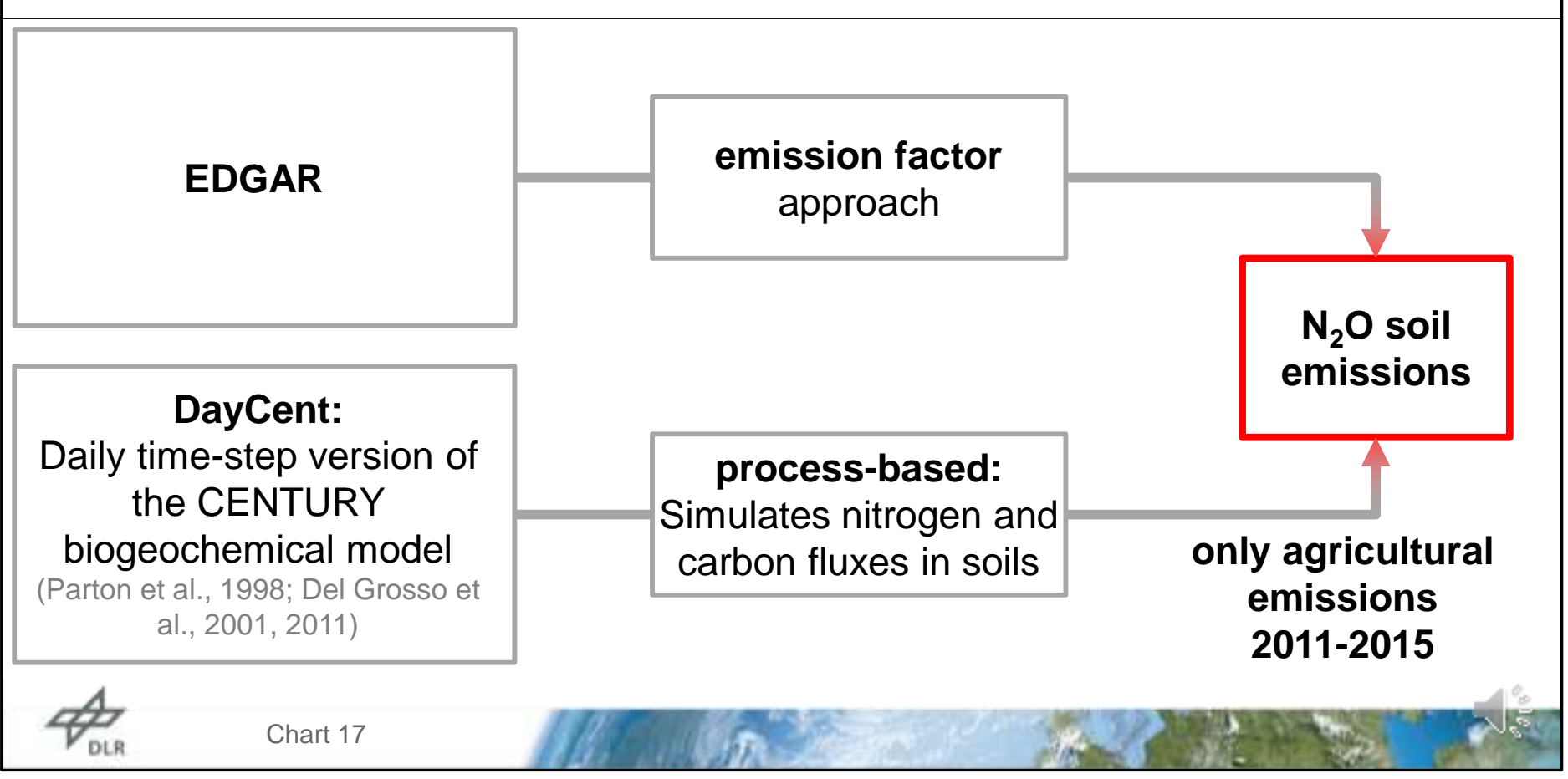


DayCent is closer to our top-down estimate than EDGAR.

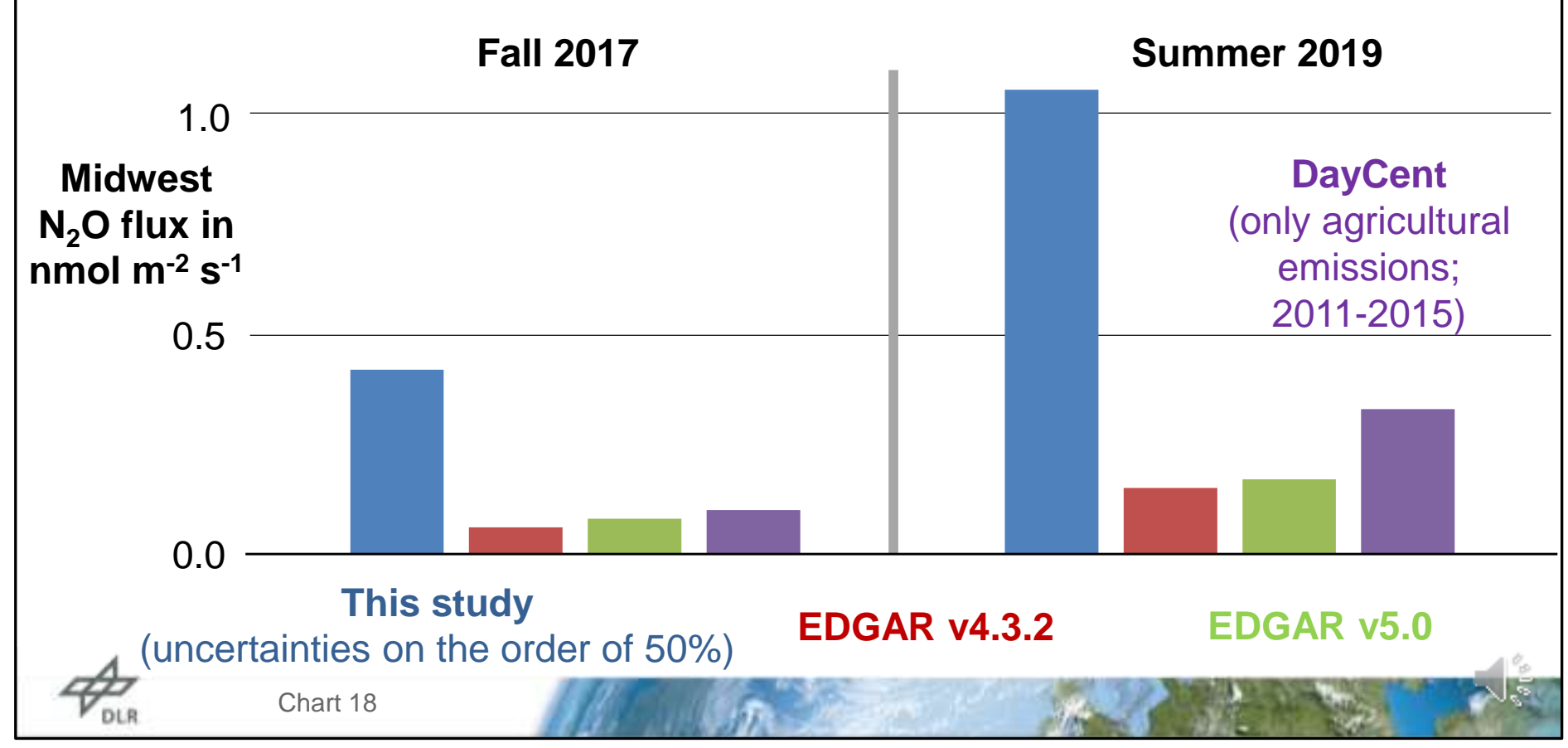




\section{Summary and Outlook}

Average Midwest $\mathrm{N}_{2} \mathrm{O}$ emissions:

- Oct 2017: $\quad 0.42 \pm 0.28 \mathrm{nmol} \mathrm{m}^{-2} \mathrm{~s}^{-1}$

- Jun/Jul 2019: $1.06 \pm 0.57 \mathrm{nmol} \mathrm{m}^{-2} \mathrm{~s}^{-1}$

EDGAR fluxes underestimate U.S.

Midwest $\mathrm{N}_{2} \mathrm{O}$ emissions by factors up

to 20

Historical DayCent Midwest $\mathrm{N}_{2} \mathrm{O}$ fluxes are closer to our top-down estimate than EDGAR but still too low

How much contributed the severe flooding event in 2019 to Midwest $\mathrm{N}_{2} \mathrm{O}$ emissions in June/July?

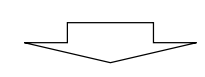

Study with DayCent simulations driven by these special conditions are planned 


\section{Summary and Outlook}

Average Midwest $\mathrm{N}_{2} \mathrm{O}$ emissions:

- Oct 2017: $\quad 0.42 \pm 0.28 \mathrm{nmol} \mathrm{m}^{-2} \mathrm{~s}^{-1}$

- Jun/Jul 2019: $1.06 \pm 0.57 \mathrm{nmol} \mathrm{m}^{-2} \mathrm{~s}^{-1}$

EDGAR fluxes underestimate U.S.

Midwest $\mathrm{N}_{2} \mathrm{O}$ emissions by factors up

to 20

Historical DayCent Midwest $\mathrm{N}_{2} \mathrm{O}$ fluxes are closer to our top-down estimate than EDGAR but still too low

\section{Live overview/Q\&A session:}

$$
\begin{gathered}
\text { Friday, 11 Dec } \\
\text { 04:48 - 04:53 PST }
\end{gathered}
$$

How much contributed the severe flooding event in 2019 to Midwest $\mathrm{N}_{2} \mathrm{O}$ emissions in June/July?

Study with DayCent simulations driven by these special conditions are planned 


\section{References (1/4)}

Baier, B. C., Sweeney, C., Choi, Y., Davis, K. J., DiGangi, J. P., Feng, S., . . Weibring, P. (2020). Multispecies Assessment of Factors Influencing Regional $\mathrm{CO}_{2}$ and $\mathrm{CH}_{4}$ Enhancements During the Winter 2017 ACT-America Campaign. Journal of Geophysical Research: Atmospheres, 125, e2019JD031339. doi: 10.1029/2019JD031339

Barkley, Z. R., Lauvaux, T., Davis, K. J., Deng, A., Miles, N. L., Richardson, S. J., . . Maasakkers, J. D. (2017). Quantifying methane emissions from natural gas production in north-eastern Pennsylvania. Atmospheric Chemistry and Physics, 17(22), 13941-13966. doi: 10.5194/acp-17-13941-2017

Butterbach-Bahl, K., Baggs, E. M., Dannenmann, M., Kiese, R., \& Zechmeister-Boltenstern, S. (2013). Nitrous oxide emissions from soils: how well do we understand the processes and their controls? Philosophical Transactions of the Royal Society B: Biological Sciences, 368, 20130122. doi: 10.1098/rstb.2013.0122

Combined Nitrous Oxide data from the NOAA/ESRL Global Monitoring Division (2020). Retrieved from https://www.esrl.noaa.gov/gmd/hats/combined/N2O.html (last accessed: 20 Jul 2020)

Del Grosso, S. J., Parton, W. J., Mosier, A. R., Hartman, M. D., Brenner, J., Ojima, D. S., \& Schimel, D. S. (2001). Simulated Interaction of Carbon Dynamics and Nitrogen Trace Gas Fluxes Using the DAYCENT Model. In M. Schaffer, L. Ma, \& S. Hansen (Eds.), Modeling Carbon and Nitrogen Dynamics for Soil Management (pp. 303-332). Boca Raton, Florida, USA: CRC Press.

Del Grosso, S. J., Parton, W. J., Keough, C. A., \& Reyes-Fox, M. (2011). Special features of the DayCent modeling package and additional procedures for parameterization, calibration, validation, and applications. In L. R. Ahuja \& L. Ma (Eds.), Methods of Introducing System Models into Agricultural Research (pp. 155-176). Madison, WI, USA: American Society of Agronomy, Crop Science Society of America, Soil Science Society of America. doi: 10.2134/advagricsystmodel2.c5 


\section{References (2/4)}

EDGAR. (2020). Emission Database for Global Atmospheric Research. Retrieved from https://edgar.jrc.ec.europa.eu/ (last accessed: 20 Jul 2020)

EDGAR4.3.2. (2017). Emissions Database for Global Atmospheric Research, version 4.3.2. European Comission. Retrieved from https://edgar.jrc.ec.europa.eu/overview.php?v=432 GHG doi: 10.2904/JRC-DATASET-EDGAR

EDGAR5.0. (2019). Emissions Database for Global Atmospheric Research, version 5.0. European Comission. Retrieved from https://edgar.jrc.ec.europa.eu/overview.php?v=50 GHG doi: 10.2904/JRC-DATASET-EDGAR

Fu, C., Lee, X., Griffis, T. J., Dlugokencky, E. J., \& Andrews, A. E. (2017). Investigation of the $\mathrm{N}_{2} \mathrm{O}$ emission strength in the U. S. Corn Belt. Atmospheric Research, 194, 66-77. doi: 10.1016/j.atmosres.2017.04.027

Kanter, D. R., Ogle, S. M., \& Winiwarter, W. (2020). Building on Paris: integrating nitrous oxide mitigation into future climate policy. Current Opinion in Environmental Sustainability, 47, 1-6. doi: 10.1016/j.cosust.2020.04.005

Kostinek, J., Roiger, A., Davis, K. J., Sweeney, C., DiGangi, J. P., Choi, Y., . . Butz, A. (2019). Adaptation and performance assessment of a quantum and interband cascade laser spectrometer for simultaneous airborne in situ observation of $\mathrm{CH}_{4}, \mathrm{C}_{2} \mathrm{H}_{6}$, $\mathrm{CO}_{2}, \mathrm{CO}$ and $\mathrm{N}_{2} \mathrm{O}$. Atmospheric Measurement Techniques, 12(3), 1767-1783. doi: 10.5194/amt-12-1767-2019

MacFarling Meure, C. (2004). The natural and anthropogenic variations of carbon dioxide, methane and nitrous oxide during the Holocene from ice core analysis (Doctoral dissertation). University of Melbourne

MacFarling Meure, C., Etheridge, D., Trudinger, C., Steele, P., Langenfelds, R., van Ommen, T., .. . Elkins, J. (2006). Law Dome $\mathrm{CO}_{2}$ $\mathrm{CH}_{4}$ and $\mathrm{N}_{2} \mathrm{O}$ ice core records extended to 2000 years BP. Geophysical Research Letters, 33(14). doi: 10.1029/2006GL026152 


\section{References (3/4)}

Myhre, G., Shindell, D., Bréon, F.-M., Collins, W., Fuglestvedt, J., Huang, J., . . . Zhang, H. (2013). Anthropogenic and Natural Radiative Forcing. In T. F. Stocker et al. (Eds.), Climate Change 2013: The Physical Science Basis. Contribution of Working Group I to the Fifth Assessment Report of the Intergovernmental Panel on Climate Change (pp. 659-740). Cambridge, United Kingdom and New York, NY, USA: Cambridge University Press

NOAA. (2020). National Centers for Environmental Information, Climate at a Glance: Regional Rankings. Retrieved from https://www.ncdc.noaa.gov/cag/ (published June 2020, retrieved on July 20, 2020)

Parton, W. J., Hartman, M., Ojima, D., \& Schimel, D. (1998). DAYCENT and its land surface submodel: description and testing. Global and Planetary Change, 19(1), 35-48. doi: 10.1016/S0921-8181(98)00040-X

Prather, M. J., Hsu, J., DeLuca, N. M., Jackman, C. H., Oman, L. D., Douglass, A. R., . . Funke, B. (2015). Measuring and modeling the lifetime of nitrous oxide including its variability. Journal of Geophysical Research: Atmospheres, 120(11), 5693-5705. doi: 10.1002/2015jd023267

Ravishankara, A. R., Daniel, J. S., \& Portmann, R. W. (2009). Nitrous Oxide $\left(\mathrm{N}_{2} \mathrm{O}\right)$ : The Dominant Ozone-Depleting Substance Emitted in the 21st Century. Science, 326(5949), 123-125. doi: 10.1126/science.1176985

Sweeney, C., Karion, A., Wolter, S., Newberger, T., Guenther, D., Higgs, J. A., . . Tans, P. P. (2015). Seasonal climatology of CO2 across North America from aircraft measurements in the NOAA/ESRL Global Greenhouse Gas Reference Network. Journal of Geophysical Research: Atmospheres, 120(10), 5155-5190. doi: 10.1002/2014jd022591 


\section{References (4/4)}

Sweeney, C., Baier, B. C., Miller, J. B., Lang, P., Miller, B. R., Lehman, S., .. Yang, M. M. (2018). ACT-America: L2 In Situ Atmospheric Gas Concentrations from Flasks, Eastern USA. ORNL Distributed Active Archive Center. Retrieved from https://daac.ornl.gov/cgi-bin/dsviewer.pl?ds id=1575 doi: 10.3334/ORNLDAAC/1575

Thompson, R. L., Lassaletta, L., Patra, P. K., Wilson, C., Wells, K. C., Gressent, A., . . Canadell, J. G. (2019). Acceleration of global $\mathrm{N}_{2} \mathrm{O}$ emissions seen from two decades of atmospheric inversion. Nature Climate Change, 9(12), 993-998. doi: 10.1038/s41558019-0613-7

Tian, H., Xu, R., Canadell, J. G., Thompson, R. L., Winiwarter, W., Suntharalingam, P., . . Yao, Y. (2020). A comprehensive quantification of global nitrous oxide sources and sinks. Nature, 586, 248-256. doi: 10.1038/s41586-020-2780-0 


\section{Summary and Outlook}

Average Midwest $\mathrm{N}_{2} \mathrm{O}$ emissions:

- Oct 2017: $\quad 0.42 \pm 0.28 \mathrm{nmol} \mathrm{m}^{-2} \mathrm{~s}^{-1}$

- Jun/Jul 2019: $1.06 \pm 0.57 \mathrm{nmol} \mathrm{m}^{-2} \mathrm{~s}^{-1}$

EDGAR fluxes underestimate U.S.

Midwest $\mathrm{N}_{2} \mathrm{O}$ emissions by factors up

to 20

Historical DayCent Midwest $\mathrm{N}_{2} \mathrm{O}$ fluxes are closer to our top-down estimate than EDGAR but still too low

\section{Live overview/Q\&A session:}

$$
\begin{gathered}
\text { Friday, } 11 \text { Dec } \\
\text { 04:48 - 04:53 PST }
\end{gathered}
$$

How much contributed the severe flooding event in 2019 to Midwest $\mathrm{N}_{2} \mathrm{O}$ emissions in June/July?

Study with DayCent simulations driven by these special conditions are planned 